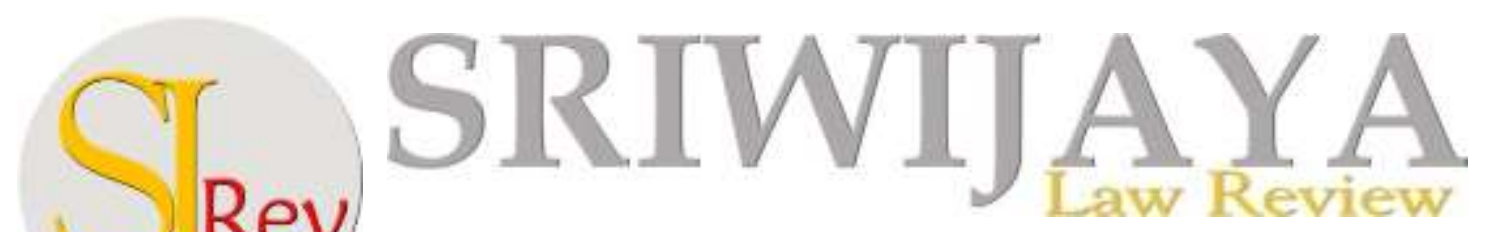

Editorial Office: Faculty of Law, Sriwijaya University, Jalan Srijaya Negara,

Palembang, South Sumatra 30139, Indonesia.

Phone: +62711-580063Fax: +62711-581179

ISSN Print: 2541-5298

E-mail: sriwijayalawreview@unsri.ac.id| sriwijayalawreview@gmail.com

ISSN Online: 2541-6464

Website: http://journal.fh.unsri.ac.id/index.php/sriwijayalawreview

\title{
Legal Aspects of Zakat Empowerment In Indonesia
}

\section{KN Sofyan Hasan* and Taroman Pasyah**}

\begin{abstract}
Zakat is a number of certain assets that the Muslim people have to give to the persons who are in need. However there are some problems in the zakat management in Indonesia. The objective of this article is to provide for a brief picture of the zakat management in Indonesia. The findings of the research conducted that it was found in 2011 that the Zakat agencies have been able to manage up to ten billion rupiahs which distribution covers the whole parts of Indonesia. Nevertheless, in Indonesia zakat has a big potential, by having $87 \%$ of Muslim populations and $20 \%$ of them are assumed as the zakat givers (muzakki). Therefore as it was reported in 2011 that the potential value of zakat was around Rp 217 trillions. In addition, the zakat added with infaq calculated around Rp 1.5 trillion per year. Meaning that the zakat collected has not reached even more than 1 percent of the potential zakat per year. Even though the number of Muslim people in Indonesia is very significant, the problems centered in the management of the zakat which is still in traditional pattern where the zakat givers (muzakki) give directly to the persons who has the right to receive zakat (mustahik). It is suggested that it need revolutionary improvement in the zakat management, there must be a mindset changing from traditional management to modern zakat management where the zakat officer (amil zakat) must be a professional one, and permanent job basis. This surely will improve the zakat management and the poverty will surely be eliminated. This research used empirical methods including the effectiveness and impact of the law.
\end{abstract}

Keywords: Infaq; Muzakki; Mustahik; Zakat; Zakat Empowerment; Zakat Agency.

\section{ARTICLE HISTORY:}

\section{DOI: 10.28946/sIrev.Vol3.Iss1.120.pp59-74}

Received: Feb 02, 2018;

Reviewed: Jan 28, 2019;

Accepted: Jan 30, 2019;

Published: Jan 31, 2019.

* Faculty of Law, Universitas Sriwijaya. E-mail: kn.sofyan_hasan@yahoo.co.id

** Faculty of Law, Universitas Sriwijaya. E-mail: taromanp@yahoo.com

\section{INTRODUCTION}

When the Prophet Muhammad PBUH SAW or Peace Be Upon Him $(\mathrm{PBUH})^{1}$ was in

SAW/Peace Be Upon Him (PBUH) hereinafter cited as PBUH.
Mecca until the first year after the Hijrah, ${ }^{2}$ he established an obligation concerning the wealth of the Muslims which should be shared, but it was still called as sadaqah ${ }^{3}$ -

2 Hijrah is the Arabic term which means migration. Hereinafter cited as Hijrah. Historically the Hijrah refers to the migration of Prophet Muhammad PBUH from Mecca to Medina. Right now the term refer to the Islamic year.

3 In the Kamus Besar Bahasa Indonesia, sadaqah means a voluntarily gift to the poors who are in need. 2. Feast (selamatan; kenduri: -- arwah; -kubur; 3. Food (flowers, etc) presented to the spirits or the souls (guardian spirit, etc). Furthermore cited as Sadaqah. 
which had no rules as in zakat ${ }^{4}$. After the Prophet Muhammad PBUH had migrated to Medina, the new zakat was commanded in detail. Then, varieties of properties which zakat should be shared, values of zakat to be shared, and ways to share the zakat were set $^{5}$. Furthermore, Abdul Ghofur ${ }^{6}$ said that after commanded in detail in the $2^{\text {nd }}$ Hijriah, the implementation was handed over to the givers themselves, without any state officers doing the zakat collection. In the $9^{\text {th }}$ Hijriah, the Prophet Muhammad PBUH, finally, regulated a rule which commands that zakat should be collected by particular officers.

Furthermore, Abdul Ghofur ${ }^{7}$ said that, in Asia, zakat has been known among the nations of Ancient East Asia, particularly among religious groups. It is proven by a view of life among the eastern nations who believe that leaving the worldly pleasures are a commendable and pious deed. In contrast, having a worldly wealth will deter

4 Zakat is the Arabic term which means the sacred. Zakat means 1 number of certain assets that must be issued by people who are Muslim and given to groups who have the right to receive them (poor people etc.) according to the provisions determined by syarak; 2 one of the pillars of Islam that must be issued to mustahik; nature of zakat which must be given by every Muslim held every day (at Eid al-Fitr) which consists of daily staple food (rice, corn, etc.); - mall zakat which is obliged to be given because it holds (possesses) assets (money, gold, etc.) which are sufficient conditions; - the profession of zakat given by every Muslim, who receives professional imbalances received, such as salaries and honoraria. Hereinafter cited as zakat.

5 Rachmat Djatnika, Pandangan Islam tentang Infak, Sadakah, Zakat dan Wakaf sebagai Komponen dalam Pembangunan, Surabaya: AlIkhlas, 1983, p18.

6 Abdul Ghofur Anshori, Hukum dan Pemberdayaan Zakat: Upaya Sinergi Wajib Zakat dan Pajak di Indonesia, Yogyakarta: PILAR, 2006, p5.

7 Note 6. people from living in happiness in heaven ${ }^{8}$. Similar to the situation in Indonesia, since Islam came to our land, zakat has become one of the sources of fund for the sake of Islamic religion development.

In the past, in the struggle of the Indonesian people against the colonization, zakat, especially the sabilillah, ${ }^{9}$ is a source of fund struggle $^{10}$. Even according to Nuruddin Muhd. Ali ${ }^{11}$, zakat has a prime position in fiscal policy in the early days of Islam. At that time, zakat is a major source of Islamic state revenue that is also able to support the expenditure of the state both in the form of government expenditure and government transfer. Furthermore, Nuruddin said that the zakat is also able to influence the economic policy of the Islamic government to improve the welfare of the people, especially the weak. Currently, the utilization of zakat has been intensively initiated to place its functions. However, it is still not coordinated thoroughly and only in the form of partial discretion ${ }^{12}$. In fact, wellorganized zakat will be very useful not only for Muslims but also for non-Muslims, so says Hazairin, as re-elaborated by Mohammad Daud Ali ${ }^{13}$.

Note 6.

9 The eight groups who are entitled to receive the zakat (al-Ashnaf al-Tsamaniyyah). Hereinafter cited as fii-sabilillah.

10 Abdullah Nasih Ulwan, Hukum Zakat dalam Pandangan Empat Mazhab, diterjemahkan oleh Didin Hafidhuddin, Jakarta: Litera Antar Nusa, 1985, p32.

11 Nuruddin Muhd Ali, Zakat sebagai Instrumen dalam kebijaksan Fiskal, Jakarta: Raja Grafindo Persada, 2006.

12 Rachmat Djatnika, Pandangan Islam tentang Infak, Sadakah, Zakat dan Wakaf sebagai Komponen dalam Pmbangunan, Surabaya: AlIkhlas, 1983, p18.

13 Mohammad Daud Ali, Sistem Ekonomi Islam: Zakat dan Wakaf, Jakarta: UI-Press, 1988, p36. 
Therefore, for a developing country like Indonesia, it would be ineffective if the zakat is distributed directly to the zakat receivers $^{14}$ (mustahik). This will make the treasure run out and the essence of zakat will fade away. As Soeharto (the Indonesia President) once pointed out during the celebration of Isra Mi'raj ${ }^{15}$ at the State Palace on October 22, 1968, he strongly advised to systematically collect zakat in an organized way. Furthermore, Soeharto's suggestion has been a driving force for the establishment of zakat agency in various part of Indonesia. For example the Government of Jakarta during the Ali Sadikin administration established the Zakat, Infaq and Sadaqah Agency ${ }^{16}$ known as BAZIS DKI. This make it possible although Indonesia is not religious State but it provides the possibility for the state officials to assist the implementation of zakat. ${ }^{17} \mathrm{In}$ Islam, zakat is not just for the act of charity in the sense of relation to Allah SWT (HablumminAllah) notwithstanding, Islam encour-ages that zakat will nourish the mutual help among the Muslim people. Ibrahim Hosen, as quoted by KN. Sofyan Hasan $^{18}$ asserted that the government has to regulate the management of zakat which has different practice among the Muslim society in Indonesia. In the Koran, especially in the

14 The persons who has the right to receive zakat, namely Mustahik.

15 Isra Mi'raj is the night journey of the Prophet Muhammad PBUH from the Mecca to the Aqsa Mosque in Jerusalem.

16 Abdul Ghofur Anshori. Note 1. pp9.

17 Mohammad Daud Ali. Note 6. p33.

18 K.N. Sofyan Hasan, Sistem Ekonomi Islam: Zakat dan Wakaf, Palembang: Penerbit Univertas Sriwijaya, 2001, p32; citing Ibrahim Hosen, "Zakat Merupakan Sarana Efektif dalam Mewujudkan Kesejahteraan Umat Islam dan Pembangunan Bangsa," (Paper, 7 October 1987), p9.
At-Taubah verse 103, has given legality and authority to the government to manage, organize, and improve the utilization of this charity by taking into account the interests and the welfare of the Islamic people (ummah). ${ }^{19}$

Furthermore, Ahmad Saefuddin ${ }^{20}$ mentioned that the implementation of zakat by the State will support the formation of a state of economic growth with equity, increased productivity together with equity of income and increased employment for the community. Apart from that, according to Mohammad Daud Ali, ${ }^{21}$ if zakat collected by the State there would be several advantages among others: The zakat obligatory is more disciplined in fulfilling its obligations and the poor are more secure of their rights, since the poors will not be perceived as the beggars, the distribution of zakat will be more orderly, the zakat which is intended for public interest such as sabilillah can be properly distributed.

Zakat is the only worship in the Islamic teachings (Sharia) which requires the zakat officers (amil). Herein, there will be two kinds of models in the zakat management. First, zakat is administered by the State in a special institution or department established by the government. Secondly, the zakat is managed by a non-governmental institution (community) or semi-governmental institution with reference to the rules set by the State. In view of this, the zakat managed by the State is not intended to meet the needs of the State such as to finance the development and other routine costs. Zakat administered by the State will be collected and distributed

19 Mohammad Daud Ali. Note 17.

20 Ahmad M. Saifuddin, Ekonomi dan Masyarakat dalam Perspektif Islam, Jakarta: Rajawali Pers, 1987, p71.

21 Mohammad Daud Ali. Note 6. p52. 
to the right Muslim persons who are in need. Thus, the state herein is function as the facilitator. In the treasury of Islamic jurisprudence, there are some views about the authority of zakat management by the State. Some argue that the new zakat may be administered by a State based on Islam, but others argue that in principle, zakat should be given to the amil - zakat officersregardless of whether the amil was appointed by the state or amil working independently within the Muslim community itself.

In Indonesia, the zakat management system has been regulated in several regulations. Firstly, the 1951 Circular Letter of the Ministry of Religious Affairs ${ }^{22}$ which declared that the State would only supervised and not interfere with the zakat collection and the zakat distribution. However, the existence of the Circular Letter above did not give affect the improvement of the zakat management in Indonesia. Then, the Agreement between the Minister of Domestic Affairs and the Minister of Religious Affairs of the Republic of Indonesia No. 29 and 47 of 1991 on the Development of Zakat, Infaq and Sadaqah Agency, followed by the Instruction of the Minister of Religious Affairs No. 5 of 1991 on Technical Guidance of Zakat, Infaq and Sadaqah Officers (Amil) and the Instruction Minister of Domestic Affairs No. 7 of 1998 on General Guidance of Zakat, Infaq and Sadaqah Officers (Amil). ${ }^{23}$ The last effort is through the development of the zakat agency namely BAZIS such as it was established in

2 No. A/VII/17367.

23 Sirojudin, Legislasi Hukum Islam di Indonesia, Yogyakarta: Pustaka Pelajar, 2008, p22.
Jakarta. ${ }^{24}$ These kinds of regulations and instructions has encouraged the growth of BAZIS and zakat institution managed by the community in other areas. It's climax was in 1999 when the government and the House of Representatives approved the 1999 Law No 38 on the Management of Zakat. Zakat Management then implemented by the 1999 Minister of Religious Affairs No. 581 on the Implementation of the 1999 Law No.38 and the Decree of General Director of Islamic Guidance and Hajj Affairs No D/291 of 2000 on Technical Guidance of Zakat Management. Previously, in 1997, there was a Decree of the Minister of Social Affairs No. 19/1998, which authorized the community to administer social welfare services for the poor to collect funds and to receive and distribute Zakat, Infaq, and Sadaqah (ZIS).

The 1999 Law No. 38 on the Management of Zakat have been revised by the 2011 Law No. 23 on the Zakat Management, ${ }^{25}$ After the passing of the UUPZ, Indonesia has entered the institutionalization stage of zakat management in the formal territory of the state, although it is still very limited. Zakat management institutions began to develop, including the establishment of government-administered zakat institutions, namely Central BAZNAS (Central National Zakat Agency), Provincial BAZNAS, Regency/City BAZNAS and LAZ (Zakat Officers Agency) managed by the community with better management and modern.

At least, the UUPZ has mentioned early on encouraged the efforts to establish a

\footnotetext{
24 No. Cb. $14 / 8 / 18 / 68$ dated the $5^{\text {th }}$ December 1968 concerning the establishment of the zakat agency based on the Islamic law in the region of Jakarta.

25 Hereinafter referred as Law of Zakat Management (Undang-undang Pengelolaan Zakat).
} 
trustful, strong and community-trusted zakat management agency. This is of course, increased the management of zakat so that the role of zakat becomes more optimal. The zakat institutions have been able to manage funds up to ten of billions rupiah (2011) collected from all areas of Indonesia. Now, the potentiality of zakat in Indonesia is enormous. If the composition of Muslims people is $87 \%$ and $20 \%$ of them are assumed as zakat giver ${ }^{26}$, therefore the potential value of zakat collected based on the research of BAZNAS with the Bogor Agricultural Institute from January to April 2011 totalling $\mathrm{Rp} 217$ trillions. It is in contradictory to the total zakat fund collected nationally Rp. 1.5 trillion/annum coupled with infaq, sadaqah, and waqf, yet has not reached one percent of the whole potential zakat. For example in 2014 the National Zakat Agency of South Sumatra Province has collected the potential zakat in South Sumatra was Rp 2.3 trillion per year. This amount is questionable. Since the real count in 2014 the number was not more than $\mathrm{Rp}$ 20 Billion. $^{27}$

\section{METHOD}

This research was an empirical research by selecting the site research in the districts of Muara Enim and Musi Banyuasin. The informants were chosed purposely based on their expertise.

\section{PROBLEMS}

Based on the description of the above background, the issue raised in this study is:The zakat empowerment in the province of South Sumatra, especially in Muara Enim

26 Muzakki is the zakat giver.

27 http://sumsel.tribunnews.com/2014/10/14/potensizakat-di-sumsel-rp-23-triliun, (retrieved: May 6, 2016).
Regency and Musi Banyuasin Regency are not properly managed. As a result, the zakat will not able to eradicate poverty.

\section{RESEARCH METHODS}

This study is an empirical study which examines the effectiveness and the impact of the law. ${ }^{28}$ Guided interview is the technique to obtain data through interpersonal private face-to-face role. Structured interview is designed to obtain answer relevant to the research problem. ${ }^{29}$ The informants were selected purposely that match to the criterion of the study, ${ }^{30}$ likewise, authority, knowledge, and experience. ${ }^{31}$ The secondary data gathered through data documentation.

\section{ANALYSIS AND DISCUSSION Efforts to the Empowerment Zakat in South Sumatra Especially in Musi Banyuasin Regency}

From the datum attained indicates that the collection of zakat was still convey in the mosque and the mushollah (chapel) by individual person. There were also community member gave their zakat individually to those they consider entitled to receive it, whether zakat al-Maal or zakat al-fitr. This information is similar to what has been conveyed by Hakut Rizon. ${ }^{32}$ For detail prochedure of zakat collecting as illustrated below.

28 Amiruddin dan Zainal Askin, Pengantar Metode Penelitian Hukum, Jakarta: PT Raja Grafindo Persada, 2010, p82.

29 Note 28.

30 http://www.answers.com/topic/purposivesampling, (retrieved: June 7, 2016).

31 http://www.wadsworth.com/psychology_d/templa tes/student_resources/workshops/res_methd/samp ling/sampling_29. html, (retrieved: June 7, 2016)

32 Head of Sub-Division of Administration of the Ministry of Religious Affairs Musi Banyuasin Regency. 
Table 1. Empowerment of Zakat In Musi Banyuasin Regency ${ }^{33}$

\begin{tabular}{|c|c|c|}
\hline No. & $\begin{array}{l}\text { Empowerment of } \\
\text { Zakat Al-Maal } \\
\text { and Zakat Al-fitr }\end{array}$ & Information \\
\hline 1 & $\begin{array}{l}\text { By Mosque-based } \\
\text { Amil Agency }\end{array}$ & $\begin{array}{l}\text { Given directly to eight } \\
\text { asnafs-parties worthy of } \\
\text { receiving zakat- if there } \\
\text { are no eight asnafs (the } \\
\text { asnafs is a variety) } \\
\text { sometimes the remaining } \\
\text { money will be returned } \\
\text { for mosque develop- } \\
\text { ment. }\end{array}$ \\
\hline 2 & $\begin{array}{l}\text { By Mushollah- } \\
\text { based Amil } \\
\text { Agency }\end{array}$ & $\begin{array}{l}\text { Given directly to eight } \\
\text { asnafs, if none of the } \\
\text { eight asnafs exists, the } \\
\text { remaining money will be } \\
\text { returned for the } \\
\text { development of } \\
\text { mushollah (mushollah is } \\
\text { a place of prayer). }\end{array}$ \\
\hline 3 & Individuals & $\begin{array}{l}\text { Be handed over to those } \\
\text { deemed entitled to } \\
\text { receive it. }\end{array}$ \\
\hline 4 & $\begin{array}{l}\text { National Zakat } \\
\text { Agency }\end{array}$ & $\begin{array}{l}\text { BAZNAS, institutions } \\
\text { that manage and } \\
\text { empower } \\
\text { nationally. }\end{array}$ \\
\hline
\end{tabular}

Based on the data above, it showed that the empowerment of zakat in Musi Banyuasin Regency was developing. In contradictory at the national level where the empowerment of zakat is not so optimum. This is because the public, in general, has not understood with the emergence of the BAZNAS institutions. People still prefer to pay the zakat in a conventional manner. Handed directly to the individual person or paid directly to the amil zakat agency of the mosque.

In the peoples' view, paying directly to the person in need is the most appropriate way to pay zakat. The obligation to pay

33 Data Source: Interview with Chairman of BAZNAS Musi Banyuasin Regency. zakat based on its nishab ${ }^{34}$ to the zakat alMaal (al-maal is property) is for every Muslims.

In the zakat al-Maal, the property becomes the main factor in the imposition of zakat. Where according to the scholars, the type of property that must be paid for zakat are cattles, grains, fruits, money (dirham or silver) and minerals. While regarding the zakat al-fitr, it is associated with the month of Ramadan and Eid al-fitr, all Muslims perform the obligation of fasting and the obligation to pay zakat al-fitr.

Zakat al-fitr is the zakat that is obliged for all Muslims without discrimination of sex and ages. The person who does not issue the zakat al-fitr when capable, then he/she will be regarded as a person who deviates from the provisions of Islamic Law (Syara').

Zakat al-fitr is not specified on nishab ${ }^{35}$ but on the adequacy of a muzakki, ${ }^{36}$ meaning that people who really do not have the sufficiency of the basic needs of his life are not obliged to pay zakat al-fitr, even the person becomes the mustahik ${ }^{37}$ of the charity, and he will get a share of zakat alfitr because he/she belongs to the person who is entitled to receive it. Zakat is one of the pillars of Islam which became one of the main elements for the establishment of Islamic law. Therefore, the law of zakat is an obligatory ${ }^{38}$ upon every Muslim who has fulfilled certain conditions. The Zakat belongs to the category of worship (such as prayer, pilgrimage, and fasting) which has been arranged in detail based on the Koran

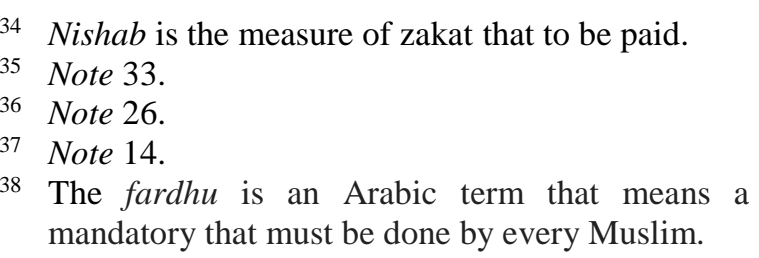
mandatory that must be done by every Muslim. 
and As-Sunnah, ${ }^{39}$ as well as a social charity of humanity that can develop in accordance with the development of mankind.

All Salafs $\mathrm{s}^{40}$ and Khalafs ${ }^{41}$ scholars stipulate that denying the law of zakat will lead to kufr. ${ }^{42}$ The above information has given an understanding of the importance of paying and distributing zakat al-Maal and zakat al-fitr to mustahiks who are entitled to receive it. Accordingly, at present, in Indonesia and in the countryside in particular, related to the acceptance and distribution of zakat al-fitr in society, it is still done by the agency of mosques or mushollahs, though the government has issued regulations related to optimizing payment and distribution of zakat to those who are entitled to receive it. ${ }^{43}$

In line with the government, Islamic law has first provided the provisions related

39 Etymologically, Sunnah is an Arabic word which means "habit". In terms of sunnah is a path that is taken by the Prophet and his companions, both knowledge, belief, speech, action, and determination.

40 The Salaf are three generations of early Muslims namely the Companions, Tabi'in and Tabi'ut Tabi'in (are an early Muslim who lived after the Companions of the Prophet and did not experience the lifetime of the Prophet Muhammad PBUH. They are younger than the Companions of the Prophet, even some who are still children or adolescents in the time of Friends are still alive. Tabi'in is a student of the Companions of the Prophet). Then the term salaf is used as one of the methods (manhaj) in the Islamic religion, which teaches The Islamic law (Shari'a) in a pure way without any additional or subtraction, namely Salafiyah. Someone who follows the three generations above, this is called Salafy (asSalafy), plural is Salafiyyun (as-Salafiyyun). Then the salafy assume that, if someone does an act without the provision of Allah and His Messenger, it can be said to be an act of heresy.

41 Khalaf, literally means a substitute, behind, or can also be left behind. This means that khalaf scholars are ulama after tabi'at-tabi'in.

42 Note 48 supra.

43 Note 22 and 23 infra. to zakat. However, the institutions established by the government still have not been implemented perfectly as the public still believes that giving zakat through the agency of mosques or mushollahs will be better. In fact, according to respondences during conducting the research, it would be better if the zakat is directly given to the right one without the intermediary state institutions such as mosques and mushollahs agency. Accordingly the zakat accepted by the mosques and mushollahs agency should met the requirements such as:

1. Zakat accepted by the mosque or mushollahs agency must be distributed to the right receiver at least there are eight asnafs $^{44}$ who are entitled to receive it.

2. Zakat received shall not be allocated elsewhere other than asnafs as specified in the Koran.

From the above explanation, the understanding one will view that one entitled to get zakat based on the Koran is divided into eight (parts). This is in line with the results of our interview with the head of Sub-Division of Administration of the Ministry of Religious Affairs of Musi Banyuasin Regency. However, if the zakat has been allocated to non-mustahiks, then its empowerment has violated the existing provisions.

Table 2. People who are entitled to receive zakat

\begin{tabular}{lll}
\hline No & $\begin{array}{l}\text { Entitled } \\
\text { People }\end{array}$ & \multicolumn{1}{c}{ Information } \\
\hline 1 & Fakir & $\begin{array}{l}\text { People who are very miserable } \\
\text { of their lives have no wealth and } \\
\text { power to fulfill their livelihood. }\end{array}$ \\
\hline 2 & Poor & $\begin{array}{l}\text { People who are not sufficiently } \\
\text { livelihood and in a state of }\end{array}$ \\
\hline
\end{tabular}

44 The person who are eligible to receive the zakat. 


\begin{tabular}{|c|c|c|}
\hline & & deprivation. \\
\hline 3 & $\begin{array}{l}\text { Amil } \\
\text { Agency }\end{array}$ & $\begin{array}{l}\text { (Badan Amil is a board or agency } \\
\text { stipulated by the government) }\end{array}$ \\
\hline 4 & $\begin{array}{l}\text { Muallaf } \\
\text { (Convert) }\end{array}$ & $\begin{array}{l}\text { The unbelievers of hope for } \\
\text { conversion to Islam and new } \\
\text { converts to Islam whose faith is } \\
\text { still weak. }\end{array}$ \\
\hline 5 & $\begin{array}{l}\text { Hamba } \\
\text { sahaya } \\
\text { (Slaves) }\end{array}$ & $\begin{array}{l}\text { Includes also to release Muslims } \\
\text { who are held captive by } \\
\text { unbelievers. }\end{array}$ \\
\hline 6 & $\begin{array}{l}\text { Ghorim } \\
\text { (Debtors) }\end{array}$ & $\begin{array}{l}\text { The person owed for a non- } \\
\text { immoral interest and unable to } \\
\text { pay it. The person who owes to } \\
\text { maintain the unity of Muslims is } \\
\text { paid the debt with zakat, } \\
\text { although he can afford it. }\end{array}$ \\
\hline 7 & $\begin{array}{l}\text { Fisabilillah } \\
\text { (Fighters in } \\
\text { Allah Glory } \\
\text { to Him and } \\
\text { Supreme } \\
\text { (Subhanahu } \\
\text { wa } \\
\text { Ta'ala)'s } \\
\text { path) }\end{array}$ & $\begin{array}{l}\text { People who are struggling, trying } \\
\text { and doing activities to uphold } \\
\text { and exalt Allah Glory to Him } \\
\text { and Supreme (Subhanahu wa } \\
\text { Ta'ala)'s religion. }\end{array}$ \\
\hline 8 & $\begin{array}{l}\text { Ibnu sabil } \\
\text { (Traveller) }\end{array}$ & $\begin{array}{l}\text { Travelers who are not having } \\
\text { immoral journey suffering on the } \\
\text { way. }\end{array}$ \\
\hline
\end{tabular}

Source: Qs. At Taubah: Verse 60

From the table as illustrated above, one can see that there are eight asnafs -parties worthy of receiving zakat- have certain causes that require it to get zakat. Although at this time there are some groups that some people consider it irrelevant to be given zakat. However, zakat is not necessarily directly allocated elsewhere, for example; allocated to the boarding school or inserted into the mosque's cash in addition to the construction of the mosque. The scholars differ on the use of zakat funds for the construction of mosques. According to Imam Syafi'i, Imam An-nasa'i, Abu Tsur, Abu Hanifah, and Imam Malik as quoted by Didin Hafidhuddin, prioritized giving zakat to the poor until all their needs were met. If the amount of zakat is large, other mustahik are entitled to receive zakat from it ${ }^{45}$.

So, it is very clear the difference between zakat with virtue and good deeds to the poor and needy people called by other religions:

1. Zakat in Islam is not merely a virtue and good deed but is one of the main Islamic fundamentalisms. People who do not pay zakat are considered wicked and deniers are regarded as kufr. ${ }^{46}$ Zakat is not a virtue either sincerely or unbound sadaqah, but it is a moral and religious obligation that is absolutely essential to be implemented.

2. Zakat according to the Islamic view is the right of the poor, the poor in the wealth of the rich. The right is fixed by the owner of the real wealth, that is, Allah Glory to Him and Supreme (Subhanahu wa Ta'ala) SWT. He obliges it to His servants whom He trusts and entrusts Him to. Therefore, there is no form of merit or mercy in the charity that the rich give to the poor.

45 Didin Hafidhuddin, Panduan Praktis tentang Zakat Infak Sedekah, Jakarta: Gema Insani, 2008, p135.

$46 K u f r$ in Arabic means covering and concealing something. In the rule of Islamic law, shar' $i$ terminology means "disbelieving in Allah and His Messenger, whether that is accompanied by denial or it is not accompanied by denial but rather doubt, or turning away from faith out of jealousy or arrogance, or because one is following whims and desires that prevent one from following the message. So kufr is the attribute of everyone who rejects something that Allaah has commanded us to believe in, after news of that has reached him, whether he rejects it in his heart without uttering it, or he speaks those words of rejection without believing it in his heart, or he does both; or he does an action which is described in the texts as putting one beyond the pale of faith. 
3. Zakat is a predetermined obligation, which has nishab, quantity, boundaries, terms, time and manner of payment.

4. This obligation is not left to human will but must be borne by the responsibility of collecting and distributing it by the government. It is done through the amil, and zakat itself is a tax that must be collected, not submitted to the goodwill of one person only.

5. The state has the authority to sanction anyone who is not willing to pay the obligations, but this can only be done in an Islamic country and cannot be applied in Indonesia. The maximum punishment given is the confiscation of half of his property.

6. Defiant armed groups from paying zakat should be killed and declared war to them by the Muslims until they are willing to pay the right of Allah Glory to Him and Supreme (Subhanahu wa Ta'ala)SWT and the poor in their wealth.

7. If the state neglects to run it or the society do not want to do it, then an individual still must perform it as a suggestion of worship and get closer to Allah Glory to Him and Supreme (Subhanahu wa Ta'ala) SWT. If the government does not oblige, then as a believer, we must implement in accordance with the provisions of the Qur'an, sunnah and ijma' (Islamic scholars' agreement).

8. The zakat wealth should not be handed over to the authorities, the religious leaders, as in the Jewish religion, but must be issued according to the expenditure goals and the people who are entitled in the Qur'an.
9. Zakat is not just a food aid at any time to slightly alleviate the suffering of the lives of the poor and then their fate is no longer ignored. But zakat aims to tackle poverty, wants the poor to be self-reliant and independent of others.

10. Zakat based on expenditure goals affirmed by the Qur'an and explained by sunnah proved able to achieve spiritual, moral, social, and political objectives. And therefore, zakat is expelled for the converts, slaves, debtors, and for the struggle in the way of Allah Glory to Him and Supreme (Subhanahu wa Ta'ala) SWT, and thus wider and more far-reaching than zakat in other religions.

\section{Empowerment of Zakat in Muara Enim Regency}

Based on the results of interviews with the Chairman of the National Amil Zakat Agency of Muara Enim Regency, the empowerment of zakat in Muara Enim Regency is done through two alternative channels, through productive service and consumptive service.

Table 3. Empowerment Concept Empowered By BAZNAS, Muara Enim Regency

\begin{tabular}{|c|c|c|}
\hline No & $\begin{array}{l}\text { Zakat Empowerment } \\
\text { in Muara Enim } \\
\text { Regency }\end{array}$ & Information \\
\hline 1 & $\begin{array}{l}\text { Through Productive } \\
\text { Empowerment }\end{array}$ & $\begin{array}{l}\text { Physical forms of } \\
\text { assistance, such as } \\
\text { vegetable carts, stalls } \\
\text { selling for street } \\
\text { vendors. }\end{array}$ \\
\hline 2 & $\begin{array}{l}\text { Through Consumptive } \\
\text { Empowerment }\end{array}$ & $\begin{array}{l}\text { The form of direct } \\
\text { assistance in the form } \\
\text { of cash. This is } \\
\text { according to the } \\
\text { interview. }\end{array}$ \\
\hline
\end{tabular}

Source: analyzed from primary data. 
Based on the above table it can be explained that the empowerment of zakat in Muara Enim Regency is done through two alternatives; namely productive empowerment and consumptive empowerment. However, the results of information in the field stated that consumptive empowerment is still not effective because people still think that the money given to them is a free aid that does not need to be accountable. Therefore, consumptive empowerment is difficult to improve the welfare of the community. But BAZNAS continues to provide services through consumptive empowerment with different concepts.

Table 4. The Concept of Zakat Empowerment, Muara Enim Regency

\begin{tabular}{|c|c|c|c|}
\hline No & $\begin{array}{c}\text { Zakat } \\
\text { Empowerment }\end{array}$ & $\begin{array}{c}\text { Concept Done } \\
\text { by BAZNAS }\end{array}$ & Information \\
\hline 1 & $\begin{array}{l}\text { Given Aid In } \\
\text { Cash Without } \\
\text { Any } \\
\text { Agreement. }\end{array}$ & - & $\begin{array}{l}\text { Does not } \\
\text { work }\end{array}$ \\
\hline 2 & $\begin{array}{l}\text { Given Aid in } \\
\text { Cash with } \\
\text { Agreement. }\end{array}$ & $\begin{array}{l}\text { 1. They are } \\
\text { directed to } \\
\text { save each } \\
\text { month in } \\
\text { BAZNAS of } \\
\text { Muara Enim } \\
\text { Regency. } \\
\text { 2. The money } \\
\text { they save } \\
\text { will then be } \\
\text { reused as } \\
\text { capital } \\
\text { money or to } \\
\text { expand their } \\
\text { business. }\end{array}$ & $\begin{array}{lr}\text { There } & \text { has } \\
\text { been } & a \\
\text { change } & \text { from } \\
\text { society. } & \end{array}$ \\
\hline
\end{tabular}

Source: analyzed from primary data.

Based on the above table, it can be explained that the empowerment of zakat through consumptive empowerment or direct cash grant to mustahik zakat or parties eligible to receive zakat has ever been done without any agreement. Apparently, the results could not provide a positive benefit to the mustahik who have received zakat through the consumptive empowerment. Therefore, based on information from BAZNAS of Muara Enim Regency, they have to change the concept with consumptive empowerment but by agreement.

Agreement here means to those who are entitled to get zakat and entitled to get zakat empowerment in cash, they have to promise to save in BAZNAS Muara Enim regency per month. The money they have saved per month can be taken and can be reused for venture capital or to expand the existing business.

This concept is increasingly emphasized by BAZNAS of Muara Enim Regency, because this concept, according to Chairman of BAZNAS, does not violate the existing law rules, whether it is the law of the country let alone the religious law. The agreement does not mean not to give zakat to the parties entitled to receive it, but more directed to the empowerment of the zakat which has been received. Thus, the empowerment of zakat can cover all the people who have not gained the empowerment of zakat and of course, they are entitled to receive it.

In line with that, the Head of the Muara Enim Regency Religious Affairs Office is of the opinion that it is not against the law if the concept is for the benefit and the welfare of the ummah (people). Furthermore, the acceptance of zakat in Muara Enim Regency is quite large. Based on data from BAZNAS Muara Enim Regency, up to October 2016, the zakat was about 800 Million. However, the format and system that must be performed by BAZNAS as the party that 
empowers the zakat to the parties entitled to receive it must be determined.

Table 5. Zakat Empowered By National Zakat Agency (BAZNAS), Muara Enim Regency

\begin{tabular}{|c|c|c|c|}
\hline No & Zakat & Administrator & Information \\
\hline 1 & $\begin{array}{l}\text { Zakat } \\
\text { al- } \\
\text { Maal }\end{array}$ & $\begin{array}{l}\text { National Zakat } \\
\text { Agency } \\
\text { (BAZNAS) of } \\
\text { Muara Enim } \\
\text { Regency }\end{array}$ & $\begin{array}{l}\text { Zakat empowered to } \\
\text { society through the } \\
\text { services of: } \\
\text { 1. Productive } \\
\text { 2. Consumptive }\end{array}$ \\
\hline 2 & $\begin{array}{l}\text { Zakat } \\
\text { al-fitr }\end{array}$ & $\begin{array}{l}\text { Zakat Al-fitr } \\
\text { Amil Agency } \\
\text { which is } \\
\text { managed by } \\
\text { the mosque as } \\
\text { long as there is } \\
\text { a license from } \\
\text { BAZNAS of } \\
\text { the Regency }\end{array}$ & $\begin{array}{l}\text { The zakat empowered } \\
\text { by the mosque officers } \\
\text { must correspond to the } \\
\text { eight asnafs and } \\
\text { usually, the scope is } \\
\text { smaller. }\end{array}$ \\
\hline
\end{tabular}

Source: analyzed from primary data.

Based on the above table, it can be explained that the zakat received by BAZNAS Muara Enim regency consists of;

\section{Zakat Al-Maal}

Zakat Al-Maal is the zakat imposed on the property owned by the individual on the terms and conditions set out by Syara'.

Table 6. Forms of Zakat and Calculations

\begin{tabular}{|c|c|c|c|c|}
\hline No & $\begin{array}{c}\text { Type of } \\
\text { Zakat }\end{array}$ & Nishab & Value & Time \\
\hline 1 & Gold & 85 gram & $2,5 \%$ & $\begin{array}{l}\text { Every } \\
\text { year }\end{array}$ \\
\hline 2 & Silver & 642 gram & $2,5 \%$ & $\begin{array}{l}\text { Every } \\
\text { year }\end{array}$ \\
\hline 3 & $\begin{array}{l}\text { Cattle: } \\
\text { 1. Lamb } \\
\text { 2. Cow, } \\
\text { Buffalo }\end{array}$ & $\begin{array}{l}40-120 \\
\text { lambs } \\
30 \text { cows, } \\
\text { buffalos }\end{array}$ & $\begin{array}{l}1 \text { lamb } \\
1 \text { cow, } \\
\text { Buffalo }\end{array}$ & $\begin{array}{l}\text { Every } \\
\text { year } \\
\text { Every } \\
\text { year }\end{array}$ \\
\hline 4 & $\begin{array}{l}\text { Rice } \\
\text { Farming }\end{array}$ & $1.481 \mathrm{~kg}$ & $\begin{array}{l}5 \% / \\
10 \% \\
\end{array}$ & $\begin{array}{l}\text { Every } \\
\text { year }\end{array}$ \\
\hline 5 & Commerce & 85 gram & $2,5 \%$ & $\begin{array}{l}\text { Every } \\
\text { year }\end{array}$ \\
\hline
\end{tabular}

Source: analyzed from primary data.

\subsection{Gold Nishab}

Gold nishab is as much as 20 dinars, ${ }^{47}$ which is equal to 85 grams of pure gold. This requirement is based on the words of the Prophet sallallaahu 'alaihi wa sallam, "There is no obligation upon you anything that is in gold - to have 20 dinars. If you already have 20 dinars and have passed one year (haul), then there is a zakat $1 / 2$ dinar. The rest is calculated accordingly, and there is no zakat on the property, except after one year (haul). As narrated by Abu Daud, Tirmidzi that from the nishab, taken $2.5 \%$ or $1 / 40$. If it is more than nishab and has not reached the size of its multiples, then taken and included with the initial nishab. That is the strongest opinion.

\subsection{Silver nishab}

Silver Nishab is 200 dirhams (624 grams), the zakat is $1 / 40\left(2 \frac{1}{2} \%\right)=5$ dirhams $(15.6$ grams). Comparison of dirhams with grams is taken from the size of the scales used in schools in Egypt.

The explanation:

1 dirham $=3.12$ grams

200 dirhams $=200 \times 3.12$ grams $=624$ grams $^{48}$

\subsection{Cattle Nishab}

The requirement of zakat of cattle is equal to the above with additional condition that is the animal should be often grazed in grassland than in the searchable food. "And in the zakat for lambs pastured outside, if up to 40 lambs to 120 lambs..." (Narrated by Bukhari)

While the size of nishab and the issued zakat is as follows:

\footnotetext{
47 The Dinar currency is still in question wether 1 dinar is 4.25 gram of gold.

48 Sulaiman Rasjid, Fiqih Islam, Bandung: Sinar Algensindo, 2009, p202.
} 
- Cattle

Cows nishab are for 30 cows. If the number of the cows are less than 30 , then there is no need to pay zakat.

- Lambs

Lambs nishab is 40 lambs.

\subsection{Agricultural Products Nishab}

Zakat of agriculture and fruits is prescribed in Islam on the basis of the word of Allah Glory to Him and Supreme (Subhanahu wa Ta'ala), "It is He Who makes the gardens upheld and the unkept, the palm trees, the plants of varying fruit, the olives and similar pomegranate (shape and color), and not the same (taste). Eat from the fruit (that is all of it) when he bears fruit, and fulfill his right on the day of plucking the result (with his zakat issued), and do not overdo it. Allah Glory to Him and Supreme (Subhanahu wa Ta'ala) does not love those who exaggerate." (Surah al-An'am: 141).

All Islamic Scholars agree that the amount (amount) that must be issued in the zakat of plants and fruits is one tenth or ten percent $10 \%$, if the plants and fruits are doused with rainwater or water from the river flow. But if the water used uses irrigation water (by paying) and the like, then it is enough to issue zakat of five percent (5\%). For example: A farmer manages to harvest $1000 \mathrm{~kg}$ of crop. Then the size of zakat issued when using irrigation (plant flush) is $1000 \times 1 / 20=50$ $\mathrm{kg}$. If it is rain fed, $1000 \times 1 / 10=100 \mathrm{~kg}$.

Scholars of the school differ in opinions about plants and fruits which are obliged to be zakat Hanafi; all fruits and plants that come out of the earth must be zakat, except wood, grass and sugar cane. Maliki and Syafi'i; every plant and fruit that is stored for shopping purposes is obliged to be zakat, such as wheat, rice, dates and wine. While
Hambali; all plants and fruits weighed and stored must be $z a k a t^{49}$.

The Nishab seeds and fruits produced from agriculture are;

1 qaq $=60$ sha ${ }^{\prime}$

5 wasaq $=5 \times 60$ sha ' $=300$ sha'

1 sha ' $=2.175 \mathrm{~kg}$ or $3 \mathrm{~kg}$. (3.1 liters)

So, 300 sha ' $\mathrm{x} 3.1$ liters $=930$ liters (one

Nishab) $)^{50}$

\subsection{Commodity Nishab}

Merchandise zakat is assets owned by an exchange contract with the aim of earning profits, and the assets they have must be the result of their own business. Every trade property (commerce) that has reached the nishab and has passed a period of one year, zakat must be issued ${ }^{51}$.

Herein, a trader must compute the amount of merchandise value at the original price (buy), and then combined with net profit after the debt cut. For example, a trader adds up his commodities by the end of the year for a total of Rp. 200,000,000 and the net profit of Rp. 50,000,000. Meanwhile, he has a debt of Rp. 100,000,000. So the calculation is as follows:

Capital - Debt:

Rp. 200.000 .000 - Rp. $100,000,000=$ Rp. 100,000,000 so the amount of property zakat is: Rp. $100,000,000+$ Rp. 50.000 .000 $=$ Rp. 150,000,000. Zakat to be paid: Rp. $150,000,000 \times 2.5 \%=$ Rp. 3.750.000.

\section{Zakat al-fitr}

Zakat al-fitr is the obligatory self-charity of every individual Muslim man and woman who is capable of the conditions set.

49 Muhammad Jawad Mughniyah, Fiqh Lima Mazhab, translated from the original book: Al fiqh 'ala al madzahib al-khamsah, Jakarta: Lentera, 2011, p186

50 Sulaiman Rasjid. Note 48. p204

51 Didin Hafidhuddin. Note 45. p57. 
Based on the interview with the Vice Chairman II of National Zakat Agency of Muara Enim Regency that the management and empowerment of zakat al-fitr can be managed by the Amil Zakat mosque and Mushollah in Muara Enim Regency as long as there is a Permit from the Muara Enim Regency Amil Zakat Agency.

Which parties are related to the empowerment of zakat?

Parties related to the empowerment of zakat in Musi Banyuasin Regency.

According to the chairman of BAZNAS of Musi Banyuasin Regency, almost all (Satuan Kerja Perangkat Daerah usual in short (SKPD) (Regional Work Unit) and Schools in Musi Banyuasin Regency are involved in the collection of zakat funds.

\section{Table 7. Parties Related to Zakat}

\section{Empowerment}

\begin{tabular}{|c|c|c|}
\hline No & $\begin{array}{l}\text { Parties involved } \\
\text { in the } \\
\text { empowerment of } \\
\text { zakat }\end{array}$ & Information \\
\hline 1 & $\begin{array}{l}\text { National Zakat } \\
\text { Agency of Musi } \\
\text { Banyuasin } \\
\text { Regency }\end{array}$ & $\begin{array}{l}\text { Management and } \\
\text { empowerment of zakat }\end{array}$ \\
\hline 2 & $\begin{array}{l}\text { Zakat Collection } \\
\text { Unit }\end{array}$ & $\begin{array}{ll}\text { - } & \text { All SKPDs in Musi } \\
& \text { Banyuasin Regency } \\
\text { - } & \text { Schools }\end{array}$ \\
\hline
\end{tabular}

Source: analyzed from primary data.

Based on the explanation of the table above, it can be proved that the Zakat Agency is fully supported by the local government. This is evidenced by the Socialization of Optimization of Collection and Utilization of Zakat to realize the welfare of the community by the Government of Musi Banyuasin Regency (Muba) in cooperation with the Ministry of Religious Affairs of Muba and the National Zakat Agency
(BAZNAS), held on November 4, 2016. The achievement above is paralel to what had been expected by the government of Musi Banyuasin Regency where the socialization of zakat management can raise the awareness of Muslims in the fulfilment of zakat. The socialization of the zakat above can build public trust on the BAZNAS in the management of zakat in a more professional, transparent, independent, pro-active and innovative.

\section{Parties related to the empowerment of zakat in Muara Enim Regency}

Parties involved in the empowerment of zakat, based on interviews with the Chairman of BAZNAS Muara Enim Regency.

\section{Table 8. Parties Related to Zakat}

\section{Empowerment}

\begin{tabular}{|c|c|c|}
\hline No & $\begin{array}{l}\text { Parties involved } \\
\text { in the } \\
\text { empowerment of } \\
\text { zakat }\end{array}$ & Information \\
\hline 1 & $\begin{array}{l}\text { National Zakat } \\
\text { Agency of Muara } \\
\text { Enim Regency }\end{array}$ & $\begin{array}{l}\text { Management and } \\
\text { empowerment of zakat }\end{array}$ \\
\hline 2 & $\begin{array}{l}\text { Zakat Collection } \\
\text { Unit }\end{array}$ & $\begin{array}{ll}\text { - } & \text { All SKPDs in Muara } \\
& \text { Enim Regency } \\
\text { - } & \text { Schools }\end{array}$ \\
\hline
\end{tabular}

Based on the explanation above, it can be understood that BAZNAS Muara Enim Regency is an institution that manages and empowers zakat to the parties entitled to receive it. Besides, it also has a special task to establish the Unit of Zakat Collector $(\mathrm{UPZ})^{52}$ in SKPDs (Regional Work Units), and schools that exist in Muara Enim Regency. The establishment of UPZ is expected to provide facilities in the

\footnotetext{
52 Hereinafter cited as UPZ.
} 
collection for the donors of zakat who want to give their zakat as long as it has fulfilled the requirement and nishab of the provisions for zakat.

\section{Can Zakat Empowerment to Alleviate Poverty?}

According to the head of the National Zakat Agency of Musi Banyuasin Regency, zakat will be able to alleviate poverty, not only alleviate poverty in the sense of material, but also poverty in the sense of essence. Thus, in fact, the first ones are offense (Aghnia), the muzakki (zakat givers) because, with the zakat they distribute, they alleviate the poverty they have within themselves such as greedy and miserly that cleanse them from ruhiyah poverty - poverty comes from the soul. After that, the impact spread to the object of zakat.

Poverty alleviation within Islam itself must be fully supported by two instruments, namely, first, direction and guidance of religion and aqidah, and second, the legal certainty of the state. In this case, a set of laws and institutions that have a strong foundation is needed to force the Muslims who are able to pay their zakat.

\section{Empowerment of zakat can alleviate poverty in Muara Enim Regency}

Based on the data obtained during the inverview that zakat empowerment is very possible to alleviate poverty in Muara Enim Regency as long as there is intervention by the Government of the Regency- the government intervened in doing the zakat empowerment. Furthermore, he said that there are now local regulations related to the empowerment of zakat, but the Regent regulation has not been out yet. In fact, according to him, the existence of Regents' regulations or instructions will provide a very significant improvement on the development of zakat in Muara Enim Regency as until now BAZNAS Muara Enim Regency is the only one which can collect zakat as much as 800 million.

Based on the above information, it can be understood that proper management and empowerment of zakat must be supported by all institutional and government institutions. The empowerment of zakat, therefore, is very potential to alleviate poverty.

\section{CONCLUSION}

1. Efforts to empower zakat in South Sumatra, especially in Muara Enim Regency and Musi Banyuasin Regency, based on the results of research, can be explained that the management and empowerment of zakat in South Sumatra generally and in particular in the two regencies as mentioned above are done through two ways:

- Traditional/Conventional, the management and empowerment of zakat is left to amils of mosque or mushollah.

- Modern, the management and empowerment of zakat is submitted to the National Zakat Agency (BAZNAS) of the Regency through the Zakat Collecting Unit which is shaped and established by the previous BAZNAS

2. Related parties in efforts to empower zakat in South Sumatra, especially in Muara Enim and Musi Banyuasin, according to the chairman of BAZNAS of Musi Banyuasin Regency and Muara Enim Regency, are almost all the Regional Work Units (SKPDs) and schools in Musi Banyuasin and Muara Enim Regency. 
3. Proper management and empowerment of zakat are possible to eradicate poverty in southern Sumatera generally, and especially in the Muara Enim and Musi Banyuasin regencies, as stated by the chairman of BAZNAS of Muara Enim Regency, that zakat empowerment is very likely to eradicate poverty as long as there is intervention from the local Government.

\section{Suggestion}

1. In order to empower the zakat in South Sumatera, generally, and especially in Musi Banyuasin and Muara Enim regencies, it is very good to use modern ways that the management is handed over to BAZNAS, so that the empowerment of zakat can cover all layers of society that is entitled to receive it. Therefore, BAZNAS, as the management and empowering agency of zakat, should be able to convince the muzakki who wants to tithe that the property they are shared is not in one use and indeed channeled to the mustahiks (zakat receivers).

2. As the National Zakat Agency (BAZNAS), cannot implement the management of zakat empowerment as expected without the support of all parties., BAZNAS should be able to establish good cooperation with agencies including SKPD or existing schools.

3. Poverty is a common enemy, meaning how concrete solutions to solve the problem. BAZNAS will not be able to solve the problem of poverty individually. Therefore, the local government must support the management and empowerment of zakat so that its management and empowerment can indeed cover the poor or who are entitled to receive it.

\section{REFERENCES}

\section{Books}

Al Qur'anul Karim. 2002. Alqur'an Dan Terjemahannya. Jakarta: Diterjemahkan oleh: Yayasan Penyelenggara Al Qur'an. Disempurnakan oleh: Lajnah Pentashih Mushaf Al Qur'an, CV Darus Sunnah.

Anshori, Abdul Ghofur. 2006. Hukum dan Pemberdayaan Zakat: Upaya Sinergi Wajib Zakat dan Pajak di Indonesia. Yogyakarta: PILAR.

Saifuddin, Ahmad M. 1987. Ekonomi dan Masyarakat; dalam Perspetif Islam. Jakarta: Rajawali Pers.

Askin, Zainal dan Amiruddin. 2010. Pengantar Metode Penelitian Hukum. Jakarta: Raja Grafindo Persada.

al-Buny, Djaal-Maaluddi. 1983. Problematika Harta dan Zakat. Surabaya: Bina Ilmu.

Hafidhuddin, Didin. 2008. Zakat Infak Dan Sedekah. Jakarta: Gema Insani.

Hasan, K.N. Sofyan. 2001. Zakat dan Wakaf. Palembang: Penerbit Universitas Sriwijaya.

Ali, Mohammad Daud. 1988. Sistem Ekonomi Islam: Zakat dan Wakaf. Jakarta: UI-Press.

Mughniyah, Muhammad Jawad. 2011. Fiqh Lima Mazhab. Diterjemahkan dari buku aslinya Al fiqh 'ala al madzahib al-khamsah. Jakarta: Lentera.

Ali, Nuruddin Mhd. 2006. Zakat Sebagai Instrumen Dalam Kebijakan Fiskal. Jakarta: Raja Grafindo Persada. 
Djatnika, Rachmat. 1983. Pandangan Islam tentang Infak. Sadakah, Zakat dan Wakaf sebagai Komponen dalam Pembangunan. Surabaya: Al-Ikhlas.

Sirajuddin. 2008. Legislasi Hukum Islam di Indonesia. Yogyakarta: Pustaka Belajar.

Rasjid, Sulaiman. 2009. Fiqih Islam. Bandung: Sinar Algensindo Bandung.

\section{Laws}

Undang-Undang Nomor 23 Tahun 2011 tentang Pengelolaan Zakat.

Peraturan Pemerintah Nomor 14 tahun 2014 tentang pengelolaan Zakat.
Kompilasi Hukum Islam, Buku I tentang Perkawinan, Bab II tentang-dasar Perkawinan.

\section{World Wide Web}

http://sumsel.tribunnews.com/2014/10/14/po tensi-zakat-di-sumsel-rp-23-triliun, [retrieved: May 6, 2016].

http://www.answers.com/topic/purposivesampling, [retrieved: June 7, 2016].

http://www.wadsworth.com/psychology_d/t emplates/student_resources/workshops/res_ methd/sampling/sampling_29. html, [retrieved: June 7, 2016]. 